\title{
Seroproteksi Antibodi Anti-Pertusis pada Anak Usia 6-7 Tahun dengan Riwayat Vaksinasi DTP Dasar Lengkap dan Ulangan di Sekolah Dasar di Jakarta
}

\author{
Runi Deasiyanti \\ Departemen Ilmu Kesehatan Anak Fakultas Kedokteran Universitas Indonesia, Rumah Sakit Dr. Cipto \\ Mangunkusumo, Jakarta
}

\begin{abstract}
Latar belakang. Angka kejadian pertusis semakin meningkat selama dua dekade terakhir walaupun cakupan vaksinasi DTP sudah cukup tinggi. Peningkatan insidens kasus pertusis terutama terlihat pada usia remaja dan dewasa, sehingga menjadi sumber penular yang penting terhadap bayi kecil. Kekebalan yang menurun merupakan salah satu penyebab peningkatan insidens pertusis sehingga kebutuhan booster pertusis pada usia remaja dan dewasa menjadi perhatian para peneliti.

Tujuan. Mengetahui proporsi seroproteksi dan rerata kadar antibodi anti-pertusis pada anak usia 6-7 tahun di Jakarta, baik yang mendapatkan vaksinasi dasar DTP (3 kali) maupun yang mendapatkan vaksinasi dasar dan ulangan (lebih dari 3 kali).

Metode. Uji potong lintang deskriptif dilakukan di enam sekolah dasar di Jakarta selama Mei-Juli 2010. Subjek adalah anak usia 6-7 tahun (siswa SD kelas 1) yang telah mendapatkan vaksinasi DTP 3 kali atau lebih. Pada setiap subjek dilakukan pemeriksaan kadar antibodi anti-pertusis.

Hasil. Subjek 75 orang anak, 38 lelaki dan 37 perempuan diikutsertakan dalam penelitian, rerata usia $(6,2 \pm 0,41)$ tahun. Sebagian besar subjek (68\%) memiliki status gizi baik dan 1 subjek $(1,3 \%)$ dengan gizi buruk. Tiga puluh delapan $(50,7 \%)$ subjek dengan riwayat vaksinasi DTP sebanyak 3 kali, $31(41,3 \%)$ subjek dengan riwayat vaksinasi 4 kali, dan 6 (8\%) subjek dengan riwayat vaksinasi 5 kali. Didapatkan proporsi antibodi antipertusis dengan seropositif $56 \%$. Seroproteksi antibodi anti-pertusis pada subjek yang mendapatkan vaksinasi DTP 3 kali adalah $50 \%$, pada subjek dengan riwayat vaksinasi 4 kali $54,8 \%$ dan pada subjek dengan riwayat vaksinasi 5 kali 100\%. Rentang kadar antibodi anti-pertusis $(0-1437,2) \mathrm{EU} / \mathrm{mL}$. Nilai median seroproteksi antibodi anti-pertusis pada subjek dengan riwayat vaksinasi DTP 3 kali adalah $43,6 \mathrm{EU} / \mathrm{mL}$, riwayat vaksinasi 4 kali $104 \mathrm{EU} / \mathrm{mL}$, dan riwayat vaksinasi 5 kali 104,9 EU/mL.

Kesimpulan. Kekebalan yang didapat dari vaksinasi tidak dapat bertahan lama, sehingga diperlukan pemberian vaksinasi ulangan (booster), baik pada usia 18-24 bulan dan usia sekolah (SD kelas 1). Selain itu juga perlu dipertimbangkan pemberian booster pada usia remaja. Sari Pediatri 2011;13(1):26-32.
\end{abstract}

Kata kunci: pertusis, vaksinasi DTP, seroproteksi, booster

\footnotetext{
Alamat korespondensi:

Dr. Runi Deasiyanti, SpA. Departemen Ilmu Kesehatan Anak FKUI-

RSCM. Jl. Salemba no. 6, Jakarta 10430, Telp. 021-3914126.
} 
S ejak era vaksinasi kasus pertusis jauh berkurang, namun berbagai penelitian epidemiologi membuktikan bahwa kasus pertusis semakin meningkat dua dekade terakhir walaupun cakupan vaksinasi DTP sudah cukup baik. Peningkatan insidens kasus pertusis terutama terlihat pada usia remaja dan dewasa. ${ }^{1,2,3}$ Kekebalan yang menurun beberapa tahun setelah vaksinasi merupakan faktor penting terhadap peningkatan kejadian pertusis. ${ }^{1,2,4}$ Kenyataan ini memberikan pertanyaan dan lahan penelitian bagi para ahli mengenai kebutuhan booster (vaksinasi ulangan) pertusis pada usia remaja dan dewasa dalam menghadapi tantangan untuk mengeradikasi pertusis. ${ }^{1,2}$

Dilakukan penelitian yang bertujuan mengetahui proporsi seroproteksi antibodi anti-pertusis pada anak usia sekolah dasar, saat kadar antibodi anti-pertusis diperkirakan sudah mulai menurun.

\section{Metode}

Penelitian deskriptif analitik dengan desain potong lintang dilakukan di enam sekolah dasar di Jakarta yaitu SD Kenari 01, SD Kenari 03, SD Kenari 05, SD Menteng 01, SD Nizamia Andalusia, dan SD PSKD pada bulan Mei-Juli 2010. Populasi target penelitian adalah anak usia 6-7 tahun (siswa SD kelas I) yang telah mendapatkan vaksinasi DTP 3 kali atau lebih dari 3 kali serta masih memiliki catatan imunisasi. Subjek yang memiliki riwayat cara pengambilan subjek menggunakan metode consecutive sampling sampai jumlah sampel terpenuhi. Seluruh orangtua subjek penelitian diminta untuk menandatangani surat persetujuan penelitian (informed consent). Penelitian telah disetujui oleh Panitia Tetap Penilai Etik Penelitian, Fakultas Kedokteran Universitas Indonesia.

Karakteristik dasar mencakup usia, jenis kelamin, status nutrisi dan riwayat vaksinasi DTP. Pemeriksaan titer antibodi dilakukan dengan teknik enzyme-linked immunosorbent assay (ELISA) menggunakan kit Bordetella Pertussis IgG ELISA yang dibuat oleh PT Indec Diagnostics, di laboratorium PT Biofarma, Bandung. Titer antibodi anti-PT proteksi bila $>24$ $\mathrm{EU} / \mathrm{ml}$.

Data dianalisis dengan menggunakan program SPSS versi 11.5 . Perbandingan rerata proporsi antibodi anti-pertusis menggunakan t-test untuk data dengan distribusi normal, dan uji Mann-Whitney untuk data dengan distribusi tidak normal. Asosiasi antara kadar antibodi anti-pertusis dengan beberapa variabel menggunakan uji Chi-square untuk data dengan distribusi normal, dan uji Fischer untuk data dengan distribusi tidak normal. Nilai $\mathrm{p}<0,05$ dianggap bermakna secara statistik.

\section{Hasil}

Penelitian melibatkan 75 subjek siswa sekolah dasar kelas I. Selama periode Mei sampai Juli 2010, telah dilakukan penyebaran kuesioner mengenai status vaksinasi DTP dan kepemilikan catatan vaksinasi pada seluruh siswa kelas I SD Kenari 01, SD Kenari 03, SD Kenari 05, SD Menteng 01, SD Nizamia Andalusia, dan SD PSKD untuk mendapatkan jumlah sampel minimal 74 subjek.

Sekolah dasar Kenari 01, SD Kenari 03, SD Kenari 05, dan SD PSKD mewakili kelompok sosial menengah ke bawah sehingga diharapkan didapatkan banyak subjek yang hanya mendapatkan vaksinasi dasar DTP sebanyak 3 kali. Sekolah dasar Menteng 01 dan SD Nizamia Andalusia mewakili kelompok sosial menengah ke atas sehingga diharapkan banyak subjek yang mendapatkan vaksinasi ulangan DTP (lebih dari 3 kali). Peneliti membagikan 238 kuesioner dan hanya 139 kuesioner yang kembali. Dari kuesioner yang kembali tersebut, peneliti memilih subjek yang memenuhi kriteria inklusi, yaitu yang telah mendapatkan vaksinasi DTP paling sedikit 3 kali dan masih memiliki catatan imunisasi.

Karakteristik subjek penelitian pada Tabel 1 memperlihatkan rasio anak laki-laki sebanding dengan anak perempuan dengan rerata usia dari seluruh subjek

Tabel 1. Sebaran subjek menurut karakteristik $(\mathrm{n}=75)$

\begin{tabular}{lcc}
\hline Karakteristik subjek & Jumlah & Persen \\
\hline Jenis kelamin & & \\
$\quad$ Laki-laki & 38 & 50,7 \\
$\quad$ Perempuan & 37 & 49,3 \\
Kelompok usia (rerata, SB), tahun & $6,2($ SB 0,41$)$ \\
$\quad 6$ & 59 & 78,7 \\
7 & 16 & 21,3 \\
Status gizi & & \\
$\quad$ Buruk & 1 & 1,3 \\
$\quad$ Kurang & 23 & 30,7 \\
$\quad$ Baik & 51 & 68,0 \\
\hline
\end{tabular}


Runi Deasiyanti: Seroproteksi antibodi anti-pertusis pada anak usia 6-7 tahun dengan riwayat vaksinasi DTP dasar lengkap dan ulangan di sekolah dasar di Jakarta

Tabel 2. Sebaran subjek menurut asal sekolah dan riwayat vaksinasi DTP $(n=75)$

\begin{tabular}{lccc}
\hline Sekolah dasar & \multicolumn{3}{c}{ Vaksinasi DTP } \\
\cline { 2 - 4 } & 3 kali & 4 kali & 5 kali \\
\hline SD Kenari 01 $(\mathrm{n}=11)$ & 9 & 2 & 0 \\
SD Kenari 03 $(\mathrm{n}=8)$ & 8 & 0 & 0 \\
SD Kenari 05 $(\mathrm{n}=8)$ & 8 & 0 & 0 \\
SD Menteng 01 $(\mathrm{n}=16)$ & 2 & 14 & 0 \\
SD Nizamia Andalusia $(\mathrm{n}=16)$ & 3 & 7 & 6 \\
SD PSKD $(\mathrm{n}=16)$ & 8 & 8 & 0 \\
\hline Jumlah, $\mathrm{n}(\%)$ & $38(50,7)$ & $31(41,3)$ & $6(8,0)$ \\
\hline
\end{tabular}

Tabel 3. Sebaran subjek menurut seroproteksi antibodi anti-pertusis

\begin{tabular}{lcc}
\hline \multirow{2}{*}{ Imunisasi DTP } & & \\
\cline { 2 - 3 } & Protektif & Tidak protektif \\
\hline 3 kali n, (\%) & $19(25,3)$ & $19(25,3)$ \\
4 kali & $17(22,7)$ & $14(18,7)$ \\
5 kali & $6(8,0)$ & $0(0,0)$ \\
\hline Jumlah & $42(56)$ & $33(44)$ \\
\hline
\end{tabular}

Tabel 4. Seroproteksi berdasarkan riwayat vaksinasi DTP

\begin{tabular}{lccc}
\hline Riwayat DTP & Jumlah & Protektif & Persen \\
\hline 3 kali & 38 & 19 & 50 \\
4 kali & 31 & 17 & 54,8 \\
5 kali & 6 & 6 & 100 \\
\hline
\end{tabular}

6,2 tahun (SB 0,41 tahun). Sebagian besar subjek $(68,0 \%)$ mempunyai status gizi baik dan hanya 1 subjek $(1,3 \%)$ yang mempunyai status gizi buruk. Rerata BB dari seluruh subjek 23,3 (SB 6,5) kg dan rerata tinggi badan $121,5(\mathrm{SB} 7,9) \mathrm{cm}$.

Sebagian besar subjek $(50,7 \%)$ hanya mendapatkan vaksinasi DTP 3 kali dan hanya 8\% subjek yang mendapatkan vaksinasi sebanyak 5 kali.

Secara keseluruhan, pada penelitian ini didapatkan proporsi antibodi anti-pertusis yang seropositif 56\%, sedangkan hasil seronegatif didapatkan pada $44 \%$ subjek. Namun apabila dilihat dari riwayat vaksinasi DTP, jumlah subjek yang memiliki kadar antibodi anti-pertusis yang protektif dan tidak protektif ternyata hampir serupa.

Tabel 4 memperlihatkan bahwa dari 38 subjek yang mendapatkan vaksinasi DTP 3 kali, 19 subjek

Tabel 5. Perbedaan nilai rerata dan rerata kadar antibodi anti-pertusis menurut beberapa variabel

\begin{tabular}{lcccccc}
\hline \multirow{2}{*}{ Variabel } & \multicolumn{3}{c}{$\begin{array}{c}\text { Tidak protektif } \\
(\mathrm{n}=33)\end{array}$} & \multicolumn{2}{c}{$\begin{array}{c}\text { Protektif } \\
(\mathrm{n}=42)\end{array}$} \\
\cline { 2 - 7 } & Rerata $(\mathrm{SB})^{*}$ & Median & $\mathrm{p}$ & Rerata $(\mathrm{SB})^{*}$ & Median & $\mathrm{p}$ \\
\hline $\begin{array}{l}\text { Jenis kelamin } \\
\quad \text { Laki-laki }\end{array}$ & $1,5(4,4)$ & 0,0 & 0,140 & $227,0(329,2)$ & 7,1 & 0,144 \\
$\quad \begin{array}{l}\text { Perempuan } \\
\text { Kelompok usia (tahun) }\end{array}$ & $5,1(8,1)$ & 0,0 & & $108,0(123,6)$ & 4,3 & \\
$\quad 6$ & $3,8(7,7)$ & 0,0 & 0,595 & $185,7(283,8)$ & 5,2 & 0,527 \\
7 & $2,3(3,5)$ & 0,0 & & $119,7(130,4)$ & 7,7 & \\
$\quad$ Riwayat DTP (kali) & & & & & & \\
3 & $2,4(5,5)$ & 0,0 & 0,293 & $94,6(128,8)$ & 43,6 & \\
4 & $4,9(8,4)$ & 0,0 & & $245,5(356,4)$ & 104,0 & 0,093 \\
5 & $0,0(0,0)$ & - & & $217,5(226,8)$ & 104,9 & 0,105 \\
& & & & & &
\end{tabular}

Ket: uji Kruskal Wallis ranking atau uji Mann Whitney ranking

* Rerata: EU/mL 
Runi Deasiyanti: Seroproteksi antibodi anti-pertusis pada anak usia 6-7 tahun dengan riwayat vaksinasi DTP dasar lengkap dan ulangan di sekolah dasar di Jakarta

(50\%) memiliki kadar yang protektif dan 19 subjek $(50 \%)$ memiliki kadar yang tidak protektif. Begitu pula dengan 31 subjek yang mendapatkan vaksinasi DTP 4 kali, 17 subjek (55\%) memiliki kadar protektif dan 14 subjek (45\%) memiliki kadar tidak protektif. Sedangkan enam subjek yang mendapatkan vaksinasi DTP 5 kali semuanya (100\%) memiliki kadar antibodi anti-pertusis yang protektif. Apabila dilihat secara keseluruhan, proporsi seroproteksi antibodi anti-pertusis pada subjek yang mendapatkan vaksinasi dasar DTP (3 kali) adalah $25 \%$, dan yang mendapatkan vaksinasi dasar dan ulangan (lebih dari 3 kali) adalah 31\%.

Dari seluruh subjek penelitian, 23 subjek (31\%) memiliki kadar antibodi anti-pertusis $0 \mathrm{EU} / \mathrm{mL}$ dan $14(60 \%)$ diantaranya adalah subjek yang hanya mendapatkan vaksinasi DTP 3 kali.

Rentang kadar antibodi sangat lebar sehingga sebaran menjadi tidak normal, oleh karena itu digunakan angka median. Pada tabel 5 dapat terlihat bahwa pada kelompok dengan kadar antibodi antipertusis protektif didapatkan nilai median kadar antibodi anti-pertusis yang lebih tinggi pada kelompok laki-laki $(7,1 \mathrm{EU} / \mathrm{mL})$ dibandingkan perempuan $(4,3 \mathrm{EU} / \mathrm{mL})$, namun perbedaan ini tidak bermakna secara statistik $(p=0,144)$. Demikian pula perbedaan nilai median kadar antibodi anti-pertusis yang tidak bermakna tidak didapatkan pada kelompok usia 6 tahun dibandingkan dengan kelompok usia 7 tahun $(p=0,527)$.

Pada perbandingan kelompok berdasarkan jumlah vaksinasi DTP tampak median kadar antibodi antipertusis pada kelompok DTP 4 kali $(104,0 \mathrm{EU} / \mathrm{mL})$ lebih tinggi dibandingkan dengan kelompok DTP 3 kali $(43,6 \mathrm{EU} / \mathrm{mL})$ namun tidak bermakna secara statistik $(p=0,093)$. Begitu pula pada kelompok DTP 5 kali $(104,9 \mathrm{EU} / \mathrm{mL})$ lebih tinggi dibandingkan dengan kelompok DTP 3 kali, namun juga tidak bermakna secara statistik $(p=0,105)$.

Tabel 6 menunjukkan kadar antibodi anti-pertusis terendah dari seluruh subjek penelitian adalah $0 \mathrm{EU} /$ $\mathrm{mL}$ dan tertinggi $1437 \mathrm{EU} / \mathrm{mL}$ dengan rerata 98,5 $\mathrm{EU} / \mathrm{mL}$. Oleh karena lebarnya rentang kadar tersebut, sebaran menjadi tidak normal sehingga digunakan angka median yaitu $30,2 \mathrm{EU} / \mathrm{mL}$

Tabel 7 menjabarkan hubungan antara variabel jumlah vaksinasi DTP yang telah didapat oleh subjek penelitian. Tidak terdapat perbedaan yang bermakna dalam hal seroproteksi antibodi anti-pertusis pada subjek yang mendapatkan vaksinasi DTP 3 kali dan $>3$ kali ( $p=0,548$, OR 0,68; IK95\%:0.24-1,87).

Tabel 6. Nilai rerata, SB, dan median kadar antibodi anti-pertusis $(\mathrm{n}=75)$

\begin{tabular}{cccccc}
\hline \multirow{2}{*}{ Riwayat imunisasi DTP } & \multicolumn{3}{c}{ Titer antibodi (EU/mL) } \\
\cline { 2 - 5 } & Rerata & SB & Median & Rentang & Maks \\
\hline Protektif $(\mathrm{n}=42)$ & & & & \\
3 kali & 94,6 & 128,8 & 43,6 & 24,9 & 472,7 \\
4 kali & 245,5 & 356,4 & 104,0 & 29,5 & 1437,2 \\
5 kali & 217,5 & 226,8 & 104,9 & 37,1 & 514,9 \\
Tidak protektif $(\mathrm{n}=33)$ & 2,4 & 5,5 & 0,0 & 0,0 & 18,9 \\
3 kali & 4,9 & 8,4 & 0,0 & 0,0 & 21,9 \\
4 kali & - & - & - & - & - \\
5 kali & 98,5 & 212,4 & 30,2 & 0,0 & 1437,2 \\
Total (n=75) & & & & & \\
\hline
\end{tabular}

Tabel 7. Hubungan antara jumlah suntikan DTP dengan seroproteksi antibodi anti-pertusis $(\mathrm{n}=75)$

\begin{tabular}{ccccccc}
\hline Riwayat imunisasi DTP & \multicolumn{2}{c}{ Kecukupan (n) } & \multirow{2}{*}{ OR } & \multicolumn{2}{c}{$95 \%$ CI } \\
& Baik & Tidak & Min & Maks \\
\hline 3 kali & 19 & 19 & & & & \\
4 kali \#) & 17 & 14 & 0,548 & 0,68 & 0,24 & 1,87 \\
5 kali \#) & 6 & 0 & & & & \\
\hline
\end{tabular}

Ket: $\left.{ }^{*}\right)$ Uji mutlak Fischer, \#) Digabung pada uji statistik 
Runi Deasiyanti: Seroproteksi antibodi anti-pertusis pada anak usia 6-7 tahun dengan riwayat vaksinasi DTP dasar lengkap dan ulangan di sekolah dasar di Jakarta

\section{Pembahasan}

Usia anak yang dipilih adalah 6-7 tahun, berdasarkan beberapa penelitian yang telah ada, dilaporkan bahwa kekebalan yang diberikan oleh vaksin DTP baik yang dengan komponen whole cell maupun acellular umumnya menurun pada usia 6 tahun. - $^{5-9}$ Pada pengolahan data, usia subjek dibuat dalam hitungan tahun. Hasil dari penelitian didapatkan usia rerata subjek adalah 6,2 tahun dengan SB 0,41. Jumlah subjek laki-laki dan perempuan pada penelitian ini sebanding.

Keberhasilan vaksinasi tergantung pada status imun pejamu, serta kualitas dan kuantitas vaksin. Status imun pejamu yang berperan antara lain adalah keadaan gizi dan maturasi imunologik. Gizi yang baik berperan pada fungsi sistem imun. Bila terdapat kekurangan asam amino yang dibutuhkan dalam sintesis antibodi maka imunoglobulin yang terbentuk tidak dapat mengikat antigen dengan baik. Sehingga, faktor nutrisi ini sangat berperan pada saat subjek mendapatkan vaksinasi. ${ }^{10}$ Sebaran status gizi dinilai berdasarkan klinis dan antropometris (perhitungan BB menurut TB). Didapatkan 68\% subjek dengan gizi baik, 31\% dengan gizi kurang, dan 1\% dengan gizi buruk. Peneliti tidak dapat mengevaluasi status nutrisi saat subjek divaksinasi secara lengkap karena cukup banyak yang tidak mencantumkan berat dan panjang badan subjek pada catatan imunisasinya. Sehingga timbul pertanyaan apakah status gizi yang baik sampai saat ini berhubungan dengan antibodi yang tetap dipertahankan tinggi.

Dari seluruh subjek penelitian, 38 (51\%) subjek hanya mendapatkan vaksinasi DTP sebanyak 3 kali, dan 33 (87\%) di antaranya berasal dari SD Kenari 01, SD Kenari 03, SD Kenari 05, dan SD PSKD. Keempat SD tersebut memang merupakan SD yang dipilih untuk dapat mewakili kelompok sosial menengah ke bawah dan hanya mendapatkan vaksinasi dasar DTP (3 kali). Tiga puluh tujuh (49\%) subjek mendapatkan vaksinasi ulangan DTP ( 4 kali atau 5 kali), dan 27 (73\%) di antaranya berasal dari SD Menteng 01 dan SD Nizamia Andalusia, yaitu sekolah yang dipilih untuk mewakili kelompok sosial menengah ke atas. Secara umum dapat dilihat bahwa siswa SD negeri mendapatkan vaksinasi di Posyandu atau Puskesmas sehingga mengikuti jadwal vaksinasi sesuai rekomendasi Departemen Kesehatan, sedangkan siswa SD swasta umumnya mendapatkan vaksinasi di praktek swasta sehingga mengikuti jadwal vaksinasi sesuai rekomendasi IDAI.

Kadar antibodi anti-pertusis protektif apabila $\geq 24$ $\mathrm{EU} / \mathrm{mL}$, yang digunakan sebagai cut-off level sesuai dengan yang tertera pada leaflet kit Bordetella Pertussis IgG ELISA, PT Indec Diagnostics. Cut-off level pada penelitian lain bervariasi tergantung pada jenis alat yang digunakan. Pemberian vaksinasi ulangan (booster) dipertimbangkan pada subjek dengan kadar antibodi anti-pertusis $<24 \mathrm{EU} / \mathrm{mL}$.

Hasil seropositif pada anak usia 6-7 tahun (5,5-6 tahun setelah vaksinasi DTP ketiga) didapatkan 56\% dan seronegatif $44 \%$, dari 75 subjek. Seronegatif menunjukkan bahwa proteksi pasca vaksinasi DTP tidak bertahan lama. Vaksin DTP adalah vaksin komponen (mati, toksoid) yang terdiri dari kombinasi toksoid, adjuvant, preservasi dan pelarut, sehingga antibodi yang terbentuk tidak dapat bertahan lama dan perlu diulang pemberiannya pada interval waktu tertentu. Untuk mendapatkan herd immunity di masyarakat maka kadar antibodi protektif harus dipertahankan seumur hidup. Beberapa penelitian menunjukkan bahwa kadar antibodi anti-pertusis menurun seiring dengan bertambahnya waktu. Proporsi seropositif 56\% pada penelitian ini hampir serupa dengan penelitian oleh Lambert ${ }^{11}$ di Michigan $(\mathrm{n}=474)$ yang menunjukkan proteksi vaksin DTP 79\% pada 4 tahun pertama setelah dosis terakhir, untuk selanjutnya menurun menjadi 53\%, 35\% dan 5\% pada 4-7 tahun, 8-11 tahun, dan $>12$ tahun setelah dosis terakhir. Hal ini menunjukkan pentingnya pemberian vaksinasi ulangan pada usia 18-24 bulan dan 5 tahun untuk mempertahankan kadar protektif antibodi antipertusis dalam darah.

Proporsi seropositif dan seronegatif berdasarkan jumlah vaksinasi DTP memberikan hasil yang hampir serupa. Pada kelompok subjek yang mendapatkan vaksinasi DTP 3 kali didapatkan proporsi seropositif dan seronegatif yang sama yaitu 25,3\%, sedangkan pada kelompok subjek yang mendapatkan vaksinasi DTP 4 kali didapatkan proporsi seropositif dan seronegatif yang hampir serupa yaitu $22,7 \%$ dan $18,7 \%$. Hal ini sesuai dengan hasil analisis hubungan antara jumlah suntikan DTP dengan seroproteksi antibodi anti-pertusis pada penelitian ini yang tidak menunjukkan perbedaan yang bermakna.

Pada kelompok dengan kadar antibodi antipertusis protektif didapatkan nilai median kadar antibodi anti-pertusis yang lebih tinggi pada kelompok 
Runi Deasiyanti: Seroproteksi antibodi anti-pertusis pada anak usia 6-7 tahun dengan riwayat vaksinasi DTP dasar lengkap dan ulangan di sekolah dasar di Jakarta

laki-laki $(7,1 \mathrm{EU} / \mathrm{mL})$ dibandingkan dengan perempuan (4,3 EU/mL), namun tidak bermakna. Perbedaan yang tidak bermakna dalam hal GMT menurut jenis kelamin juga didapatkan pada penelitian di Taiwan dan Italia, ${ }^{12,13}$ namun penelitian yang dilakukan oleh Inandi $\mathrm{dkk}^{14}$ di Turki (n=781) mendapatkan geometric mean titers (GMT) yang lebih tinggi pada anak lelaki dibandingkan dengan anak perempuan.

Dari 38 subjek yang mendapatkan vaksinasi DTP 3 kali, terdapat 19 subjek (50\%) yang memiliki kadar antibodi anti-pertusis di bawah kadar protektif dan 14 diantaranya (38\%) memiliki kadar antibodi antipertusis $0 \mathrm{EU} / \mathrm{mL}$. Hasil ini serupa dengan penelitian yang dilakukan oleh Lambert ${ }^{11}$ yang mendapatkan bahwa pada 4-7 tahun setelah vaksinasi DTP terakhir tingkat serangan pertusis adalah $47 \%$. Hasil yang serupa juga didapatkan oleh Hallander $\mathrm{dkk}^{5}$ yang meneliti penurunan anti-PT pada subjek yang telah mendapatkan vaksinasi DTP sebanyak 3 kali. Pada 1 bulan pasca vaksinasi DTP ketiga, seluruh subjek memiliki kadar anti-PT di atas $5 \mathrm{EU} / \mathrm{mL}$ (cut-offlevel yang digunakan oleh penelitian tersebut) namun pada 24 bulan pasca DTP ketiga hanya sekitar 25\% subjek yang mencapai angka tersebut. Pada pengambilan sampel 6 tahun pasca DTP ketiga, terdapat kurang dari $10 \%$ yang mencapai kadar anti-PT $5 \mathrm{EU} / \mathrm{mL}$ dan $70 \%$ subjek memiliki kadar anti-PT dibawah minimum level of detection (MLD), yaitu $1 \mathrm{EU} / \mathrm{mL}$. Didapatkan 23 subjek (31\%) memiliki kadar antibodi anti-pertusis $0 \mathrm{EU} / \mathrm{mL}$.

Meskipun demikian hasil penelitian ini tidak dapat menjelaskan apakah pada subjek telah terbentuk anti-pertusis kemudian menurun atau memang sejak awal tidak terbentuk karena tidak ada data kadar awal. Kekebalan yang didapat dari subjek penelitian tidak dapat dibedakan apakah disebabkan semata-mata oleh vaksinasi atau karena infeksi alami.

Kadar antibodi anti-pertusis berkisar antara 0 $\mathrm{EU} / \mathrm{mL}$ sampai dengan $1437,2 \mathrm{EU} / \mathrm{mL}$ dengan rerata 98,5 EU/mL dan median 30,2 EU/mL. Oleh karena rentang kadar antibodi anti-pertusis yang didapatkan sangat lebar, maka sebaran menjadi tidak normal sehingga yang digunakan pada penelitian ini adalah nilai median. Hasil ini tidak dapat dibandingkan secara langsung dengan penelitian-penelitian yang ada sebelumnya karena penggunaan metode pemeriksaan dan penggunaan alat yang berbeda-beda.

Beberapa subjek memiliki kadar antibodi antipertusis yang sangat tinggi, baik pada kelompok yang hanya mendapatkan vaksinasi DTP 3 kali ataupun 4 kali. Pada kelompok yang mendapatkan vaksinasi DTP 3 kali, terdapat 2 subjek yang memiliki kadar antibodi anti-pertusis melebihi $400 \mathrm{EU} / \mathrm{mL}$. Bahkan kadar tertinggi didapatkan pada subjek yang mendapatkan vaksinasi DTP 4 kali, yaitu 1437,2 EU/mL. Hal ini memperlihatkan bahwa selain jumlah pemberian vaksinasi DTP, terdapat faktor lain yang berperan dalam mempertahankan kadar antibodi seorang anak misalnya seperti status nutrisi ataupun adanya infeksi alami. Sayangnya metode pemeriksaan pada penelitian ini tidak dapat membedakan apakah kekebalan yang dimiliki ini adalah semata-mata karena vaksinasi yang didapatkan ataukah karena subjek juga telah terinfeksi secara alami.

Kesulitan yang dihadapi pada penelitian ini antara lain adalah sedikitnya orangtua yang masih menyimpan catatan imunisasi, walaupun mereka cukup yakin bahwa anak mereka telah melengkapi imunisasi dasar DTP dan bersedia untuk ikut serta dalam penelitian. Umumnya hal ini disebabkan karena kartu KMS anak mereka disimpan di Posyandu dan sudah tidak dapat ditelusuri keberadaannya. Kepemilikan catatan imunisasi dimasukkan ke dalam kriteria inklusi untuk mencegah terjadinya recall bias.

Salah satu keterbatasan penelitian adalah pengukuran kadar antibodi anti-pertusis yang hanya dilakukan satu kali dengan desain potong-lintang sehingga penurunan kadar antibodi anti-pertusis tidak dapat terlihat dengan jelas. Kadar antibodi anti-pertusis setelah vaksinasi dasar DTP tidak diketahui sehingga tidak didapatkan data awal kadar antibodi anti-pertusis subjek sebagai petanda terbentuk atau tidaknya antibodi anti-pertusis setelah vaksinasi. Penelitian dengan desain kohort yang mengukur kadar antibodi anti-pertusis setelah vaksinasi DTP ketiga, keempat dan 6 tahun setelah vaksinasi terakhir merupakan bentuk penelitian yang ideal.

Tidak lengkapnya data berat badan dan panjang/ tinggi badan pada catatan imunisasi yang menyebabkan status nutrisi subjek pada saat mendapatkan vaksinasi tidak diketahui juga merupakan keterbatasan penelitian ini. Hal ini mengakibatkan tidak dapat disimpulkannya apakah status nutrisi yang kurang atau buruk pada saat subjek divaksinasi menyebabkan pembentukan immunoglobulin yang kurang baik.

Keterbatasan lain adalah metode ELISA yang digunakan pada penelitian ini tidak dapat membedakan apakah antibodi anti-pertusis yang didapat 
Runi Deasiyanti: Seroproteksi antibodi anti-pertusis pada anak usia 6-7 tahun dengan riwayat vaksinasi DTP dasar lengkap dan ulangan di sekolah dasar di Jakarta

disebabkan oleh vaksinasi atau infeksi alami. Penelitian dengan metode pemeriksaan yang dapat membedakan antara keduanya merupakan metode penelitian yang lebih ideal.

Disimpulkan bahwa di antara 75 orang anak berumur 6-7 tahun, kadar antibodi anti pertusis telah menurun, tergantung dari jumlah imunisasi DTP yang telah diterima. Pada kelompok DTP 3, 4, dan 5 kali berturut-turut adalah 50\%, 54\%, dan 100\% dengan kadar antibodi 43,6; 104; dan 104,9 EU/ml.

\section{Daftar pustaka}

1. Greenberg DP. Pertussis in adolescents: increasing incidence brings attention to the need for booster immunization of adolescents. Pediatr Infect Dis J 2005;24:721-8.

2. Cherry JD. The epidemiology of pertussis: a comparison of the epidemiology of the disease pertussis with the epidemiology of bordetella pertussis infection. Pediatrics 2005;115:1422-7.

3. Department of Vaccines and Biologicals, World Health Organization. Pertussis surveillance. Geneva: World Health Organization; 2001.

4. Edwards K. Overview of pertussis: focus on epidemiology, sources of infection and long term protection after infant vaccination. Pediatr Infect Dis J 2005;24:S104-S8.

5. Hallander HO, Gustafsson L, Ljungman M, Storsaeter J. Pertussis antitoxin decay after vaccination with DTPa response to a first booster dose $3 \frac{1}{2}-6 \frac{1}{2}$ years after the third vaccine dose. JVAC 2005:1-6.
6. Salmaso S, Mastrantonio P, Tozzi AE, Stefanelli P, Anemona A, Ciofli degli Atti ML, dkk. Sustained efficacy during the first 6 years of life of 3-component acellular pertussis vaccines administered in infancy: the Italian experience. Pediatrics 2001; 108:e81.

7. Jenkinson D. Duration of effectiveness of pertussis vaccine: evidence from a 10 -year community study. BMJ 1988;296:216-4.

8. Grimprel E, Begue P, Anjak I, Njamkepo E, Francois P, Guiso N. Long-term human serum antibody responses after immunization with whole-cell pertussis vaccine in France. Clin Diagn Lab Immunol 1996;3:93-7.

9. Lugauer S, Heininger U, Cherry JD, Stehr K. Long-term clinical effectiveness of an acellular pertussis component vaccine and a whole cell pertussis component vaccine. Eur J Pediatr 2002;161:142-6.

10. Matondang CS, Notoatmojo H. Aspek imunologi imunisasi. Dalam: Akib Arwin AP, Matondang CS, penyunting. Buku ajar alergi-imunologi anak. Edisi ke-2. Jakarta: IDAI, 2007. h. 154-9.

11. Lambert HJ. Epidemiology of a small pertussis outbreak in Kent County, Michigan. Public Health Rep 80:365-9.

12. Chiu TF, Lee CY, Lee PI, Lu CY, Lin HC, Huang LM. Pertussis seroepidemiology in Taipei. J Formos Med Assoc 2000;99:224-8.

13. Giammanco A, Chiarini A, Stroffolini T, de Mattia D, Chiaramonte M, Moschen ME, et al. Seroepidemiology of pertussis in Italy. Rev Infect Dis 1991;13:1216-20.

14. Inandi T, Guraksin A, Hacialioglu N. Seroprevalence of pertussis among children in Eastern Turkey. Public Health 2005;119:55-5. 